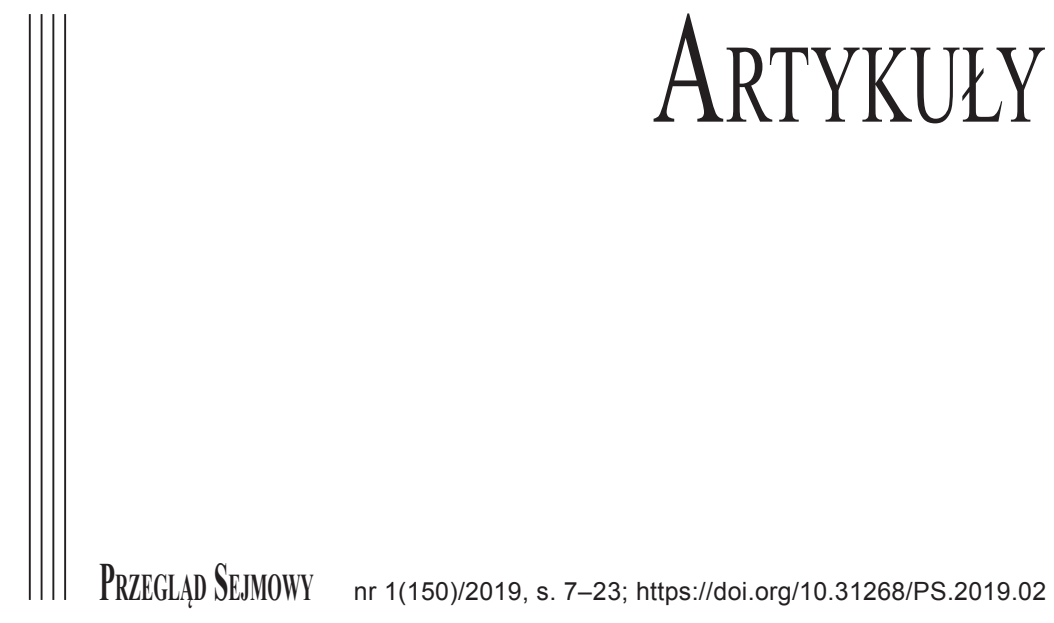

ANDRZEJ ADAMCZYK*

\title{
ROLA PARLAMENTU W BUDOWIE NOWEGO PAŃSTWA TURECKIEGO. I WIELKIE ZGROMADZENIE NARODOWE (1920-1923)
}

THE PARLIAMENT'S ROLE IN THE CONSTRUCTION OF THE NEW

TURKISH STATE. THE FIRST GRAND NATIONAL

ASSEMBLY (1920-1923)

In the article the First Turkish Grand National Assembly, operating in Ankara between 1920 and 1923, is discussed. The legal status of this organ in the light of its first legal acts of 1920 and the Constitutional Act of 20 January 1921, as well as organization of the executive power and main lines of political divisions within the parliament are examined.

Słowa kluczowe: Wielkie Zgromadzenie Narodowe Turcji, system rządów, Mustafa Kemal, Atatürk, parlament turecki

Key words: Turkish Grand National Assembly, system of governance, Mustafa Kemal, Atatürk, Turkish parliament

* Dr hab. Andrzej Adamczyk, Uniwersytet Jana Kochanowskiego w Kielcach, andrzej.adamczyk@ujk.edu.pl,https://orcid.org/0000-0002-6080-4516

1. UWAGI WSTEPNE

T mperium osmańskie w następstwie opowiedzenia się w I wojnie światowej po stronie Niemiec poniosło klęskę wojenną i znalazło się na krawędzi całkowitego upadku. Traktat z Sèvres podpisany w imieniu sułtana przez wielkiego wezyra Damada Ferida Paszę 10 sierpnia 1920 r. położył kres istnieniu imperium. Wśród elity państwa osmańskiego mocna była jednak myśl o potrzebie przeciwstawienia się okupantom i powołania instytucji wyrażających wolę narodu. Niniejsze opracowanie poświęcono I Wielkiemu Zgromadzeniu Narodowemu (Türkiye Büyük Millet Meclisi, dalej: WZN lub Zgromadzenie), funkcjonującemu w Ankarze w latach 1920-1923, 
które - zwołane pod auspicjami Stowarzyszenia Obrony Praw Anatolii i Rumelii dążyło do zachowania niezależnego bytu politycznego narodu tureckiego i nadania państwu nowego kształtu. Aspekt ustrojowo-prawny wskazujący na przyjęte rozwiązania konstytucyjne uzupełnia aspekt polityczny ilustrujący istniejące w Wielkim Zgromadzeniu Narodowemu linie podziałów.

\section{UKONSTYTUOWANIE SIE WIELKIEGO ZGROMADZENIA NARODOWEGO W ANKARZE}

Kapitulacja sułtanatu przed aliantami nakazywała czynnikom patriotycznym odwołać się do całego narodu, który w zbiorowym wysiłku mógł przeciwstawić się agresji z zewnątrz i niechybnej parcelacji ziem tureckich. $Z$ powstałego oddolnie w Anatolii ruchu oporu wyłoniła się organizacja pod nazwą Stowarzyszenie Obrony Praw Anatolii i Rumelii (czyli terytoriów tureckich w Azji i Europie), ze stałym Komitetem Reprezentacyjnym, na czele którego stanął generał Mustafa Kemal (Atatürk). Kemal nadawał jedności narodowej duże znaczenie, wierząc, że tylko wspólna walka wszystkich grup społecznych pozwoli Turcji utrzymać niepodległość. Poniekąd naturalne było nawiązanie do idei rewolucyjnego parlamentu na wzór francuskiego Konwentu Narodowego ${ }^{1}$. W wezwaniu wystosowanym 19 marca 1920 r. przez M. Kemala w imieniu Komitetu Reprezentantów Stowarzyszenia Obrony Praw Anatolii i Rumelii do generałów, gubernatorów i urzędników prowincjonalnych była mowa o konieczności wyboru nowego parlamentu wyrażającego wolę narodu oraz wyposażonego w ekstraordynaryjne kompetencje. Zwołanie parlamentu w Ankarze było spowodowane okupacją

${ }^{1}$ Wielu badaczy dostrzega inspirację kemalistów Rewolucją Francuską (H. Edib, Turkey Faces West, New Haven 1930, s. 181; D. Webster, The Turkey of Atatürk. Social Process in the Turkish Reformation, Philadelphia 1939, s. 165; F. Kentel, Nowoczesność i islam w Turcji, „Krytyka” 1994, nr 44/45, s. 151; W. Weiker, Political Tutelage and Democracy in Turkey. The Free Party and Its Aftermath, Leiden 1973, s. 73; K. Karpat, Turkey's Politics. The Transition to A Multi-Party System, Princeton 1959, s. 137; E.Z. Karal, The principles of Kemalism, [w:] Atatürk. Founder of A Modern State, red. A. Kazancigil, E. Özbudun, London 1997, s. 13; I. Orga, Phoenix Ascendant: The Rise of Modern Turkey, London 1958, s. 31; İ. Giritli, Kemalism as an Ideology of Modernization, [w:] Atatürk and the Modernization of Turkey, red. J.M. Landau, Leiden 1984, s. 251; R.L. Maddex, Constitutions of the World, Washington 2001, s. 356). Według historyka S. Shawa turecka ustawa konstytucyjna z 1921 r. odzwierciedlała jej idee oraz poglądy J.J. Rousseau, które podzielał M. Kemal (S.J. Shaw, E.K. Shaw, History of the Ottoman Empire and Modern Turkey, t. II: Reform, Revolution and Republic: The Rise of Modern Turkey 1808-1975, Cambridge 1977, s. 352). 14 lipca 1922 r. M. Kemal przedstawił ideologiczny światopogląd rewolucji tureckiej, mający swoje źródło w hasłach Rewolucji Francuskiej i francuskiej filozofii politycznej. W 1923 r. powiedział do francuskiego pisarza Pernota: „My wszyscy czerpaliśmy ze źródła kultury Francji. Rewolucja turecka jest w swym historycznym rodowodzie opóźnioną rewolucją francuską; jest ona opóźnionym echem rewolucji francuskiej” (O. Apaydın, Historyczny rozwój tureckiego prawa, „Palestra” 1978, nr 8, s. 113). W polskiej publicystyce międzywojennej zauważano, że „przez charakter swój jaskrawo anti-monarchiczny i anti-religijny przypomina ten nacjonalizm turecki burzliwy nacjonalizm francuski z czasu Wielkiej Rewolucji, której hasła wywierają dziś w Turcji niewątpliwie swój wpływ nieco spóźniony” (I. Pannenkowa, Przewrót w Turcji, „Rzeczpospolita”, 6 III 1924, nr 65, s. 3). 
Stambułu — stolicy kalifatu i sułtanatu — przez aliantów. Okupacja ta uniemożliwiała osmańskiemu rządowi i parlamentowi swobodne działanie. M. Kemal planował, że ankarski parlament będzie funkcjonował w trakcie wszystkich faz rewolucji, którą Kemal zamierzał zrealizować ${ }^{2}$. Deklarowanym celem powołania w Ankarze zgromadzenia wyposażonego w nadzwyczajne uprawnienia była jednak ochrona nienaruszalności i niezależności sułtanatu i kalifatu ${ }^{3}$.

Mustafa Kemal miał świadomość, że podejmuje działania, które nie mają podstaw w obowiązującej konstytucji osmańskiej z 1876 r., starał się więc pozyskać do udziału w nowym parlamencie Celaleddina Arifa Beya, przewodniczącego osmańskiej Izby Deputowanych i profesora prawa konstytucyjnego. Ten w korespondencji z Kemalem wskazał na rozwiązania francuskie nawiązujące do idei, która mogła stanowić fundament działań tureckiego ruchu oporu. Zauważał więc, że zgodnie z francuską konstytucją w przypadku niezgodnego z prawem rozwiązania Izby Deputowanych lub uniemożliwienia jej normalnego funkcjonowania deputowani oraz po dwie osoby wybrane przez komisje okręgowe i prowincjonalne mogli zebrać się w innym miejscu niż miejsce siedziby parlamentu, aby postanowić, jakie środki należy podjąć w celu przeciwstawienia się bezprawiu. Uchwały takiego zgromadzenia były wiążące i urzeczywistniane po dyktatorsku, a opór przeciwko nim traktowany był jak zdrada stanu ${ }^{4}$.

Wybory do Zgromadzenia miały być prawdziwie powszechne, a zasiąść w nim mieli reprezentanci wszystkich okręgów ${ }^{5}$. Deputowani ze Stambułu, którzy byli w stanie przybyć do Ankary, mogli uczestniczyć w obradach. Wybory w 1920 r. zostały przeprowadzone na podstawie prawa wyborczego z 1876 r., aby wyłoniony w nich parlament mógł zebrać się w ciągu 15 dni od dnia wezwania. Przyczyną konieczności niezwłocznego otwarcia Zgromadzenia Narodowego było zagrożenie rojalistycznymi rebeliami, które ogarniały tereny coraz bliższe Ankary. Każda partia, grupa czy stowarzyszenie mogły zgłosić własnych kandydatów na posłów, a najwyżsi rangą urzędnicy w każdym okręgu wyborczym, jakim był sandżak, byli odpowiedzialni za należyte przeprowadzenie wyborów ${ }^{6}$.

Dnia 22 kwietnia 1920 r. M. Kemal wydał okólnik dla armii i prowincjonalnej administracji, zgodnie z którym wszystkie instytucje cywilne i wojskowe miały

${ }^{2}$ M. Kemal (Atatürk), A Speech Delivered by Mustafa Kemal Atatürk 1927, Ankara 1981, s. 369.

${ }^{3}$ E.D. Smith, Turkey: Origins of the Kemalist Movement and the Government of the Grand National Assembly (1919-1923), Washington 1959, s. 31; T.Z. Tunaya, The Establishment of the Government of the Turkish Grand National Assembly and Its Political Character, „Annales de la Faculté de Droit d'Istanbul" 1963, nr 19, t. XIII, s. 49; S.J. Shaw, E.K. Shaw, op. cit., s. 349; B. Lewis, Narodziny nowoczesnej Turcji, Warszawa 1972, s. 301; D.A. Rustow, Atatürk as an Institution-builder, [w:] Atatürk. Founder of A Modern State, red. A. Kazancigıl, E. Özbudun, London 1997, s. 70. Tekst wezwania: M. Kemal (Atatürk), op. cit., s. 366-367; M. Vassaf, Die Grundideen des türkischen Staatswesen und seine stufenweise Entwicklung, „Abhandlung des Instituts für Politik, ausländisches öffentliches Recht und Völkerrecht an der Universität Leipzig", Heft 39, Leipzig 1934, s. 26-27.

${ }^{4}$ A. Adamczyk, Ustrój polityczny Turcji w latach 1918-1960, Warszawa 2013, s. 68.

${ }^{5}$ M. Vassaf, op. cit., s. 27.

${ }_{6}^{6}$ T.Z. Tunaya, The Establishment..., s. 49; E.D. Smith, op. cit., s. 32. 
podporządkować się jurysdykcji WZN7 . Wybory do Zgromadzenia zostały zdominowane przez Stowarzyszenie Obrony Praw Anatolii i Rumelii. Wydaje się jednak, że były one względnie konkurencyjne i uczciwe oraz zapewniły reprezentację w parlamencie różnych grup nigdy wcześniej w życiu politycznym imperium osmańskiego nieosiągniętą. W dniu 23 kwietnia $1920 \mathrm{r}$. ukonstytuował się jednoizbowy parlament, w którego skład weszło 232 deputowanych wybranych w wyborach do WZN oraz 106 deputowanych wybranych w ostatnich wyborach do parlamentu osmańskiego z 1920 r. $^{8}$

Na pierwszym posiedzeniu Zgromadzenia pojawiły się różne koncepcje dotyczące jego statusu prawnego. Niektórzy uważali, że jest to instytucja tymczasowo reprezentująca naród w okresie walki o wyzwolenie narodowe, inni zaś — jak Celaleddin Arif - że stanowi ono kontynuację parlamentu drugiego okresu konstytucyjnego. Według M. Kemala WZN miało być permanentnie obradującym organem, reprezentującym naród i łączącym funkcje ustawodawcze i wykonawcze ${ }^{9}$. Stanowisko to przeważyło i już 23 kwietnia 1920 r. Zgromadzenie uchwaliło deklarację, w której określono główne zasady jego organizacji ${ }^{10}$. Wskazywano na absolutną konieczność ustanowienia rządu, przy jednoczesnej niedopuszczalności uznania tymczasowej głowy państwa czy zastąpienia jej przez regenta. $\mathrm{W}$ deklaracji stwierdzono, że rzeczywistą władzą w państwie jest wola narodu reprezentowana przez Zgromadzenie, stanowiące najwyższy organ państwa, łączący w sobie zarówno kompetencje ustawodawcze, jak i wykonawcze. Rząd, określony jako „rada państwa” i mający ,prowadzić sprawy państwa”, był wybierany przez Zgromadzenie i był wobec niego odpowiedzialny zarówno solidarnie, jak i indywidualnie ${ }^{11}$. Przewodniczący WZN miał ex officio sprawować funkcję prezydenta Rady Państwa. W deklaracji nie określono stosunku Zgromadzenia do ośrodka władzy w Stambule, stwierdzono jedynie, że „Sułtan-Kalif, gdy zostanie uwolniony od nacisków, którym podlega, odnajdzie swoje miejsce w ramach ustroju konstytucyjnego w sposób określony przez Zgromadzenie"'2.

Zgromadzenie - mimo koncentracji władzy — nie mogło bezpośrednio pełnić funkcji wykonawczej w pełnym zakresie. Dlatego też musiało wybrać ze swego grona reprezentantów do prowadzenia określonych spraw ${ }^{13}$. 24 kwietnia $1920 \mathrm{r}$. M. Kemal w przemówieniu dotyczącym wydarzeń politycznych w Turcji od 16 maja

${ }^{7}$ M. Kemal (Atatürk), op. cit., s. 376; B. Lewis, op. cit., s. 427; E.D. Smith, op. cit., s. 38.

${ }^{8}$ E. Özbudun, Turkey, [w:] Competitive Elections in Developing Countries, red. M. Weiner, E. Özbudun, Durham 1987, s. 336; E.D. Smith, ibidem, s. 33; H. Türsan, Democratisation in Turkey: the role of political parties, Brussels 2004, s. 36; T.Z. Tunaya, The Establishment..., s. 52; E.D. Smith, op. cit., s. 32.

${ }^{9}$ N. Berkes, The Development of Turkish Secularism, Montreal 1964, s. 439.

${ }^{10}$ Tekst deklaracji: S. Kili, Kemalism, Istanbul 1969, s. 20; D.E. Webster, op. cit., s. 86.

${ }^{11}$ Y. Abadan, Die Entstehung der Türkei und ihre verfassungsrechtliche Entwicklung bis 1960, „Jahrbuch des öffentlichen Rechtsgeschichte” 1960, nr 9, s. 361.

12 Vide punkty 1-2 i 4 deklaracji WZN z 23 kwietnia $1920 \mathrm{r}$.

${ }_{13}$ A.F. Başgil, A Summary of Constitutional Developments in Turkey and on the Historical and Political Sources of the Present Constitution, „Annales de la Faculté de Droit d'Istanbul” 1960, nr 15, s. 88; M. Vassaf, op. cit., s. 28. 
1919 r. do chwili zwołania WZN wskazał na przesłanki koncentracji władzy w ramach Zgromadzenia, które — jego zdaniem — musiało przejąć kierowanie narodem. Uważał on, że nie należało dążyć do parlamentarno-gabinetowego systemu rządów, lecz wprowadzić rozwiązania, które sprawdziłyby się także w warunkach nadzwyczajnych. Pod uwagę brano dwie możliwości: wzmocnienie egzekutywy albo legislatywy. Według M. Kemala tylko to drugie rozwiązanie było możliwe do przyjęcia, ponieważ nie można było zezwolić na to, aby władzę wykonawczą sprawowało zaledwie kilka osób. W związku z tym wzmocnienie legislatywy miało nastąpić przez przyznanie jej władzy wykonawczej. Dla tendencji dominującej w I WZN, z którą M. Kemal musiał się liczyć, znamienne było to, że w podjęciu decyzji w przedmiocie wskazanego problemu ustrojowego należało uwzględnić zasady prawa konstytucyjnego islamu. Zdaniem Kemala były one kompatybilne z proponowanym rozwiązaniem.

W przemówieniu z 24 kwietnia 1920 r. M. Kemal zwrócił również uwagę na konieczność powołania komisji rządowej (rady państwa), wybranej spośród deputowanych. Jej członkowie wraz z prezydentem komisji mieli ponosić — indywidualnie i zbiorowo - odpowiedzialność polityczną wobec Zgromadzenia. Komisja miała przybrać nazwę Rady Wykonawczej (İcra Vekilleri Heyeti), a jej członkowie mieli nosić tytuły ministrów. Przewodniczący WZN, wybrany przez Zgromadzenie i je reprezentujący, miał być jednocześnie szefem Rady Wykonawczej, składać podpisy w imieniu WZN oraz potwierdzać decyzje Rady. Za działania wchodzące w zakres funkcji wykonawczej ponosił on odpowiedzialność przed parlamentem. Rozwiązanie to, określone jako „tworzenie rządu bez premiera”, wynikało z przybranej przez M. Kemala taktyki politycznej i było związane z jego deklarowanym przywiązaniem do sułtanatu-kalifatu. Ponieważ siedziba sułtana-kalifa, będącego zarówno zwierzchnikiem Osmanów, jak i muzułmanów, znajdowała się pod okupacją, powołanie rządu w Anatolii lub mianowanie zastępcy sułtana (regenta), traktowane choćby tylko jako tymczasowe rozwiązania, było niewskazane. Zamiast ograniczać zakres władzy WZN, należało uczynić go ogniskiem, w którym skoncentruje się wola narodu. W związku z tym nie mogło być wyższego organu władzy nad Zgromadzeniem ${ }^{14}$.

Propozycje przedłożone przez M. Kemala wywołały dyskusję w Zgromadzeniu, w następstwie której — po złożeniu wniosku przez Celaleddina Arifa — 25 kwietnia 1920 r. powołano tymczasowy siedmioosobowy Komitet Wykonawczy z M. Kemalem na czele, wybranym wcześniej na przewodniczącego WZN. Zgromadzenie wybrało również 15-osobową komisję parlamentarną mającą za zadanie opracowanie projektu ustawy o organizacji rządu ${ }^{15} .30$ kwietnia 1920 r. Tymczasowy Komitet Wykonawczy

${ }^{14}$ A. Adamczyk, op. cit., s. 70; G. Jäschke, Auf dem Wege zur Türkischen Republik. Ein Beitrag zur Verfassungsgeschichte der Türkei, „Die Welt des Islams” 1958, t. V, nr 3-4, s. 211; idem, Der Islam in der neuen Türkei. Eine Rechtsgeschichtliche Untersuchung, „Die Welt des Islams” 1951, t. I, nr 1-2, s. 28; T.Z. Tunaya, The Establishment..., s. 54-57; E.D. Smith, op. cit., s. 39-40; A.L. Macfie, Atatürk, London-New York 1994, s. 101-102; M. Vassaf, op. cit., s. 28.

15 E.D. Smith, op. cit., s. 41. 
poinformował ministrów spraw zagranicznych państw europejskich, że przejął rządy nad tureckim terytorium ${ }^{16}$. Dzień później przedstawiono parlamentowi ostateczny projekt dotyczący ustawy o organizacji rządu, który świadczył o olbrzymim wpływie M. Kemala na komisję, jako że w projekcie zawarto jego propozycje ${ }^{17}$.

Dnia 2 maja $1920 \mathrm{r}$. Zgromadzenie uchwaliło ustawę o wyborze delegatów wykonawczych. Komitet Delegatów Wykonawczych [dalej: KDW] miał się składać z 11 osób, wybieranych indywidualnie bezwzględną większością głosów przez WZN spośród jego członków, które miały zajmować się sprawami: szariatu i pobożnych fundacji, służby zdrowia i pomocy społecznej, gospodarki (handlu, przemysłu, rolnictwa, lasów i kopalni), edukacji, wymiaru sprawiedliwości i kultu, finansów (ceł i katastru), robót publicznych, spraw wewnętrznych (bezpieczeństwa publicznego, poczty i telegrafu), obrony narodowej, spraw zagranicznych, sztabu generalnego. Każdy delegat przy załatwianiu określonej sprawy mógł zasięgnąć opinii przydzielonej mu komisji, natomiast w razie konfliktu między delegatami ostateczna decyzja należała do $\mathrm{WZN}^{18}$. W ustawie nie przewidziano - wśród delegatów wykonawczych — stanowiska wielkiego wezyra ani wielkiego muftiego. Funkcje tego ostatniego wykonywał delegat wykonawczy ds. szariatu i pobożnych fundacji19.

Kształt konkurencyjnego względem stambulskiego rządu KDW w Ankarze został zmieniony ustawą $\mathrm{nr} 47$ z 4 listopada 1920 r., wedle której delegaci wykonawczy byli wybierani przez WZN spośród trzech kandydatów przedstawianych przez przewodniczącego WZN na dane stanowisko ${ }^{20}$. Z czasem opozycja wobec M. Kemala uznała to rozwiązanie za faworyzujące go jako przewodniczącego WZN i dążyła do powrotu do pierwotnego modelu wyboru delegatów. Wybierani indywidualnie delegaci nie mogli tworzyć komitetu o homogenicznej strukturze. Działając w imieniu parlamentu, byli związani wyznaczonymi przez niego granicami i w przypadku przekroczenia swoich uprawnień ponosili odpowiedzialność polityczną przed Zgromadzeniem. Za pomocą powołanych organów WZN sprawowało funkcję wykonawczą. Umocowane w tym zakresie organy czerpały $\mathrm{z}$ woli Zgromadzenia, dlatego $\mathrm{w}$ istocie były one organami WZN. W ustawie z dnia 5 września 1920 r., zwanej ustawą o kworum (Nisab-i Müzakere Капипи), przyjęto zasadę permanentnego działania Zgromadzenia oraz ustanowiono kworum w liczbie co najmniej połowy członków WZN. Każdy członek Zgromadzenia,

${ }^{16}$ G. Jäschke, Der Islam..., s. 28.

17 T.Z. Tunaya, The Establishment..., s. 58; E.D. Smith, op. cit., s. 41-42; Y. Abadan, op. cit., s. 361; G. Jäschke, Auf dem Wege..., s. 210.

18 Vide § 1-4 ustawy, której tekst w języku niemieckim znajduje się [w:] E. Pritsch, Geschichtliche und systematische Übersicht nebst Anmerkungen zur Verfassung, ,Mitteilungen des Seminars für Orientalische Sprachen zu Berlin” XXVI-XXVII (1924), t. II, s. 173; Y. Abadan, op. cit., s. 361; Z.K. Özbulak, Das türkische Verfassungssystem, Berlin 1936, s. 18.

19 Y. Abadan, op. cit., s. 370; H. Kohn, Geschichte der nationalen Bewegung im Orient, Berlin-Grunewald 1928, s. 200.

${ }^{20}$ Y. Altuğ, The Development of Constitutional Thought in Turkey, [w:] Modern Turkey: Continuity and Change, red. A. Evin, Opladen 1984, s. 133. 
który bez usprawiedliwienia lub ważnej przyczyny nie uczestniczył w obradach parlamentu przez co najmniej dwa miesiące, mógł zostać pozbawiony mandatu decyzją WZN podjętą na sesji plenarnej ${ }^{21}$.

Według M. Kemala zwołanie WZN było równoznaczne z końcem imperium osmańskiego i zniesieniem kalifatu, oznaczało ono bowiem tworzenie nowego państwa opartego na nowych podstawach, wynikających z zasady suwerenności ludu ${ }^{22}$. W swojej przemowie na kongresie Republikańskiej Partii Ludowej w 1927 r. Kemal wyznał, że walka narodowa nie była nakierowana na ochronę istniejącego ustroju, lecz na ustanowienie nowego porządku społeczno-politycznego. Zamierzenia te w początkowym okresie walki o niepodległość nie zostały w pełni ujawnione, ponieważ pierwotnym i najważniejszym celem było zwycięstwo nad wrogiem zewnętrznym. W celu osiągnięcia głównego zadania M. Kemal mobilizował różne grupy społeczne, w tym również konserwatywnie nastawionych ulemów. Niezbędne było więc używanie tradycyjnej frazeologii odwołującej się do uczuć religijnych w oświadczeniach i przemówieniach samego twórcy nowoczesnej Turcji, jak i w aktach prawnych wydawanych przez WZN 23 .

Ewidentna sprzeczność zawarta w formule „,wyzwolenie kalifatu i sułtanatu, ojczyzny i narodu, na podstawie zasady suwerenności narodu" wynikała z tego, że ruch oporu nie był pod względem społecznym jednorodny. Nie budzi wątpliwości, że I WZN było zgromadzeniem wyłonionym z szerokich kręgów społeczeństwa i z tego powodu zdecydowanie różniło się od parlamentu osmańskiego ${ }^{24}$. Pod względem struktury zawodowej I WZN składało się z: urzędników (43\%), osób związanych z handlem (12\%) i rolnictwem (6\%) oraz duchownych muzułmańskich (17\%) ${ }^{25}$. Elita wojskowo-biurokratyczna, stanowiąca przodujący element $\mathrm{w}$ WZN, a tym samym i w ruchu narodowym, była uzależniona od poparcia lokalnych notabli i przywódców religijnych, a więc grup konserwatywnych ${ }^{26}$. Dążenie do wyzwolenia kalifatu i sułtanatu, ojczyzny i narodu na podstawie zasady suwerenności narodu stało się więc jedyną realną podstawą porozumienia między różnymi grupami w WZN. Świadczy o tym treść przysięgi,

21 A.F. Başgıl, op. cit., s. 88; E. Zwierzchowski, Organizacja i funkcjonowanie Sądu Konstytucyjnego Republiki Turcji, [w:] Sady konstytucyjne w Europie. Akty normatywne wedtug stanu prawnego na dzień 1 lipca 1999 r., t. 3: Hiszpania, Portugalia, Turcja, red. J. Trzciński, Warszawa 1999, s. 202.

22 S. Kili, Kemalism..., s. 18 i n.

23 Ibidem, s. 18-19.

24 B. Tanör, The Place of Parliament in Turkey, [w:] Turkish State, Turkish Society, red. A. Finkel, N. Sirman, London-New York 1990, s. 145.

25 Vide F. Frey, The Turkish Political Elite, Cambridge 1965, s. 181. Termin „urzędnicy” używany jest tu w szerokim znaczeniu: są to osoby wykonujące funkcje państwowe (urzędnicy, wojskowi). Pozostałe grupy reprezentowane w WZN to: osoby wykonujące wolny zawód (prawnicy, lekarze) — 18\%, dziennikarze - ok. 4\%.

${ }^{26}$ D.A. Rustow, The Modernization of Turkey in Historical and Comparative Perspective, [w:] Social Change and Politics in Turkey. A Structural-Historical Analysis, red. K. Karpat, Leiden 1973, s. 11; E. Özbudun, The Nature of the Kemalist Political Regime, [w:] Atatürk. Founder of A Modern State, red. A. Kazancigil, E. Özbudun, London 1997, s. 82-83. 
składanej przez deputowanych Zgromadzenia, w której przyrzekali oni, że będą dążyli przede wszystkim do osiągnięcia jedności narodowej ${ }^{27}$.

Rewolucyjny charakter Zgromadzenia odzwierciedlały uchwalane przez nie akty prawne oraz deklaracje ${ }^{28}$. WZN stanowiło ośrodek kierowania walką o niepodległość, której celem - jak ustanowiono w ustawie o kworum - było wyzwolenie kalifatu i sułtanatu, ojczyzny i narodu na podstawie zasady suwerenności narodu ${ }^{29}$. WZN prowadziło też politykę zagraniczną oraz zajmowało się sprawami wewnętrznymi, nie pozostawiając bieżącego kierowania resortami delegatom wykonawczym na wyłączność. Program pierwszego KDW był zresztą bardzo skromny. W sferze polityki zagranicznej zapowiadano urzeczywistnienie Paktu Narodowego ${ }^{30}$, w zakresie polityki wewnętrznej przyjęto natomiast zasadę jedności narodowej, zakładano przywrócenie praworządności oraz stopniowe reformy w dziedzinie edukacji, finansów, robót publicznych i wymiaru sprawiedliwości. W zakresie wojskowości zapowiadano natomiast przekształcenie zbrojnych oddziałów ruchu oporu w regularną armię ${ }^{31}$. WZN zajmowało się też stale sferą wymiaru sprawiedliwości, powołując sądy oraz trybunały rewolucyjne. Te ostatnie działały na podstawie ustawy $\mathrm{nr} 2 \mathrm{z}$ dnia 29 kwietnia 1920 r. o zdradzie państwa, zgodnie z którą za wrogów państwa uważane

27 Przysięga ta miała następującą treść: „Nie będę kierował się żadnym innym celem niż wyzwolenie kalifatu i sułtanatu oraz niepodległość Ojczyzny i Narodu”. Była ona oparta na koncepcji przyjętej na kongresie w Sivas, na którym odrzucono podziały polityczne na rzecz jedności narodowej i walki z wrogiem (T.Z. Tunaya, The Establishment..., s. 62, przyp. 34).

${ }^{28}$ Na przykład deklaracje: do narodu (26 kwietnia 1920 r.), Komitetu Delegatów Wykonawczych (9 maja 1920 r.), populizmu (18 grudnia 1920 r.), Muzułmańskiej Komisji Religijnej (9 maja 1920 r.); telegram Wielkiego Zgromadzenia Narodowego do sułtana (28 kwietnia 1920 r.); ustawa konstytucyjna z 20 stycznia 1921 r. (T.Z. Tunaya, The Establishment..., s. 65; E.D. Smith, op. cit., s. 44).

${ }_{29}$ T.Z. Tunaya, The Establishment..., s. 63; E.D. Smith, op. cit., s. 44 i n.; G. Jäschke, Der Islam..., s. 28.

${ }^{30}$ Deklarację tę, potwierdzającą wszystkie zasady głoszone na kongresach ruchu oporu w Erzurumie i Sivasie, uchwaliła 17 lutego 1920 r. Izba Deputowanych w Stambule. Przewidywano w niej, że: 1) przyszłość wszystkich terytoriów osmańskich zamieszkanych przez ludność arabską, które znalazły się w rękach sił zbrojnych ententy, powinna zostać rozstrzygnięta w plebiscycie, reszta zaś osmańskich terytoriów zamieszkana przez osmańską i muzułmańską większość zjednoczoną wspólnym pochodzeniem etnicznym i rasowym, religią i tradycją historyczną, wreszcie aspiracjami politycznymi, miała zostać uznana za nienaruszalną jedność; 2) w okręgach Kars, Ardahan i Batumi parlament zgodził się na plebiscyt rozstrzygający, czy mieszkańcy tych obszarów chcą pozostać pod osmańską suwerennością, czy też nie; 3) prawny status zachodniej Tracji miał zostać rozstrzygnięty w plebiscycie; 4) Stambuł, jako siedziba kalifatu, sułtana i rządu, wraz z całym regionem Morza Marmara miał być całkowicie zabezpieczony przed wszelkim niebezpieczeństwem zewnętrznym; 5) gwarancje i prawa mniejszości chrześcijańskich miały zostać przyjęte przez Turcję pod warunkiem zapewnienia analogicznych uprawnień mniejszości muzułmańskiej w sąsiednich państwach; 6) Turcja miała zachować pełną i nienaruszoną w żadnej dziedzinie suwerenność i niezależność (T. Wituch, Tureckie przemiany. Dzieje Turcji 1878-1923, Warszawa 1980, s. 259). Ze względu na okupację Stambułu przez aliantów, wywołaną przyjęciem Paktu Narodowego, parlament osmański uchwalił 18 marca 1920 r. rezolucję protestacyjną, w której stwierdzono, że w zaistniałych okolicznościach nie mógł on funkcjonować skutecznie i dlatego odroczono obrady na czas nieograniczony.

31 T.Z. Tunaya, The Establishment..., s. 60; E.D. Smith, op. cit., s. 42. 
były osoby przeciwstawiające się prawu WZN oraz wzywające słowem i czynami do rozruchów ${ }^{32}$. Osoby takie mogły zostać skazane na karę śmierci. Ustawą nr 21 z 11 września 1920 r. trybunały zostały upoważnione do karania dezerterów, a w ustawie $\mathrm{nr} 28$ z dnia 26 września 1920 r. rozszerzono zakres kognicji trybunałów do karania zdrajców państwa i osób dopuszczających się czynów na rzecz wroga i osłabiających własną zdolność obronną, w tym także szpiegów. Specyfika nowo powstałych trybunałów polegała na tym, że orzekający w nich sędziowie byli wybierani spośród członków parlamentu. W ten sposób parlament realizował też uprawnienia jurysdykcyjne ${ }^{33}$.

\section{PARLAMENT W KONTEKŚCIE USTAWY KONSTYTUCYJNEJ} Z 20 STYCZNIA 1921 R.

W uchwalonej przez WZN ustawie konstytucyjnej z 20 stycznia 1921 r. potwierdzono zasadę suwerenności narodu (art. 1) przyjętą w $1920 \mathrm{r}^{34}$ Ze względu na przyjęte założenie, że suwerenność jest niepodzielna, władza rządzenia mogła być sprawowana w całości za pośrednictwem organu reprezentacyjnego, czyli jednoizbowego Wielkiego Zgromadzenia Narodowego, które koncentrowało w sobie funkcje: ustawodawczą, wykonawczą i - do pewnego stopnia - sądowniczą (zasada jedności władzy państwowej i jednoizbowości parlamentu) ${ }^{35}$. W art. 2 ustawy konstytucyjnej przewidziano, że „władza wykonawcza i ustawodawcza manifestują i koncentrują się w Wielkim Zgromadzeniu Narodowym”. Artykuł ten zawierał jednocześnie najogólniejszą formułę koncentracji władzy w formie uznania Zgromadzenia za organ, za pośrednictwem którego realizowana jest zasada suwerenności narodu. WZN było zatem ,jedynym i prawowitym reprezentantem narodu". Zgodnie z art. 3 ustawy konstytucyjnej, ,państwo tureckie kierowane jest przez Wielkie Zgromadzenie Narodowe, a jego rząd nosi nazwę Rząd Wielkiego Zgromadzenia Narodowego". W art. 8 wskazywano na to, że rząd nie jest organem wyodrębnionym organizacyjnie, lecz jedynie funkcjonalnie: „Wielkie Zgromadzenie Narodowe kieruje departamentami (ministerstwami), na które podzielony jest rząd, za pośrednictwem delegatów wykonawczych wybieranych w zgodzie z odpowiednią ustawą". W związku z taką formułą Komitet Delegatów Wykonawczych powinien być postrzegany jako organ WZN, a jego członkowie jako urzędnicy WZN.

32 Tekst ustawy, [w:] E.J. Zürcher, Political Opposition in the Early Turkish Republic. The Progressive Republican Party 1924-1925, Leiden-New York-Kobenhavn-Köln 1991, s. 124.

${ }_{33}$ O. Apaydın, op. cit., s. 114; A.L. Macfie, op. cit., s. 104.

${ }^{34}$ Tekst w języku ang., [w:] S. Kili, Turkish Constitutional Developments and Assembly Debates on the Constitution of 1924 and 1961, Istanbul 1971, s. 160-162; w języku niem., [w:] E. Hirsch, Die Verfassung der türkischen Republik, Frankfurt am Main-Berlin 1966, s. 206-208; E. Pritsch, op. cit., s. 176-178; M. Vassaf, op. cit., s. 88-90.

${ }_{35}$ T.Z. Tunaya, Ideologic Character of the 1924 Constitution, „Annales de la Faculté de Droit d'Istanbul" 1960, t. X, nr 15, s. 115; Ch. Rumpf, Das Rechtsstaatsprinzip in der türkischen Rechtsordnung. Ein Beitrag zum türkischen Verfassungsrecht und zur europäischen Rezeptionsgeschichte, Bonn-Berlin 1992, s. 53; M. Vassaf, op. cit., s. 32-33. 
Koncentracji funkcji państwowych w Zgromadzeniu towarzyszył brak instytucji ograniczających prawa parlamentu, np. brak weta ustawodawczego przysługującego wyodrębnionej jedynie funkcjonalnie, a nie organizacyjnie władzy wykonawczej. W rezultacie ciało parlamentarne posiadało całkowitą swobodę w zakresie podejmowania uchwał oraz rozpoczęcia, przebiegu i zamykania swoich obrad. Parlament rozstrzygał również o ważności wyborów i czasie trwania swojej kadencji (zasada permanencji działania parlamentu). Zmiana konstytucji była możliwa zwykłą większością głosów deputowanych, co — zdaniem Muammara Vassafa — upodabniało akt z 1921 r. do konstytucji angielskiej ${ }^{36}$. Oprócz ustaw WZN mogło uchwalać akty wykonawcze do nich (art. 7 zd. 2). Zgromadzenie z racji swojego suwerennego charakteru posiadało również kompetencje wykonawcze, które tradycyjnie przypisane są rządowi, np. zawieranie umów międzynarodowych z innymi państwami czy zaciąganie pożyczek (art. 7 zd. 1). Przy braku wzmianki w ustawie konstytucyjnej o organizacji wymiaru sprawiedliwości, a tym samym o przyznaniu sądom prawa orzekania o konstytucyjności ustaw, mogłoby się wydawać, że aktem z 1921 r. dano parlamentowi swobodę w sferze prawotwórstwa ${ }^{37}$. Niemniej jednak wśród kompetencji WZN wymieniono wykonywanie prawa szariatu oraz wskazano na konieczność uwzględniania w działalności ustawodawczej Zgromadzenia prawa islamu, tj. zarówno w stosunkach między ludźmi (mu'amalat), jak i w stosunku człowieka do Boga (ibadat). Wymóg ten złagodzono klauzulą, że przepisy prawa islamu powinny odpowiadać ,sposobowi życia (modus operandi) ludzi i wymogom

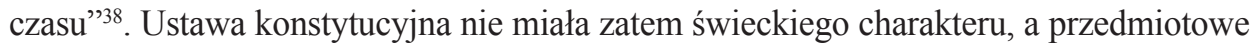
rozwiązanie świadczy o dominującej tendencji wśród deputowanych w zakresie relacji ułożenia relacji państwo-religia. Jeśli dodamy do tego oficjalnie deklarowany cel WZN, czyli wyzwolenie kalifatu i sułtanatu, ukaże się nam Zgromadzenie jako organ, w którym ścierały się sprzeczne kierunki polityczno-ustrojowe.

Szereg przepisów istotnych dla funkcjonowania WZN zostało zawieszonych do chwili zrealizowania celów określonych w ustawie z 5 września 1920 r. o kworum, tj. wyzwoleniu kraju i narodu oraz sułtanatu i kalifatu ${ }^{39}$. Zawieszony art. 4 dotyczył powoływania Zgromadzenia składającego się z członków wybranych przez ludność wilajetów na okres dwóch lat. Przewidziana w art. 5 możliwość ponownego wyboru deputowanego oraz wyjątkowego przedłużenia kadencji parlamentu o jeden rok, gdyby przeprowadzenie nowych wyborów było niemożliwe, jak i zasady wykonywania funkcji ustępującego parlamentu do chwili pierwszego posiedzenia nowego parlamentu oraz mandatu wolnego nie miały tymczasowo zastosowania. Zawieszenie objęło także art. 6, którym ustanowiono regułę, że parlament zbiera się 1 października bez zwoływania.

Komitet Delegatów Wykonawczych wybierał ze swego grona prezesa (obok prezydenta Komitetu). Prezydentem Komitetu był z urzędu przewodniczący WZN (art. 9),

${ }^{36}$ M. Vassaf, op. cit., s. 35 i n.

${ }^{37}$ A. Adamczyk, op. cit., s. 77.

${ }^{38}$ Ch. Rumpf, op. cit., s. 53; A.F. Başgil, op. cit., s. 90; S. Starzyński, Powojenny ustrój państw europejskich, Kraków 1926, s. 61.

39 A.F. Başgil, op. cit., s. 89. 
który w ramach tej funkcji potwierdzał decyzje tego ciała (art. $9 \mathrm{zd}$. 2). W tym rozwiązaniu przejawiało się prawo do sprawowania permanentnej kontroli nad komitetem wykonawczym przez przewodniczącego WZN. Jako że był on zaufaną osobą parlamentu i jako najwyższy przedstawiciel państwa cieszył się wielkim autorytetem podpisywane przez niego akty KDW były chronione przed uchyleniem ${ }^{40}$. Odrębnemu prezesowi KDW ustawą konstytucyjną powierzono zajmowanie się sprawami dotyczącymi całego gabinetu w zastępstwie przewodniczącego WZN. Prezes Komitetu był niejako wiceszefem rządu, wykonującym pod kierownictwem przewodniczącego WZN zadania związane z prowadzeniem spraw rządu ${ }^{41}$. Był on także delegatem wykonawczym WZN.

W żadnym przepisie ustawy konstytucyjnej z $1921 \mathrm{r}$. nie nawiązywano do oktrojowanej przez sułtana w 1876 r. konstytucji osmańskiej. Konstytucyjny status WZN i stwierdzenie przez nie nieważności aktów rządu w Stambule począwszy od 16 marca 1920 r. mogą stanowić podstawę do twierdzenia, że powołanie WZN zapoczątkowało nowy ustrój. Taka też była ocena tego wydarzenia dokonana przez M. Kemala ${ }^{42}$. Natomiast deklarowany cel WZN wskazywał na coś zupełnie odmiennego i dlatego w projekcie konstytucji przedłożonym przez komisję konstytucyjną w dniu 18 sierpnia 1920 r. zakładano tymczasowość WZN i jego rządu do chwili wyzwolenia sułtanatu i kalifatu ${ }^{43}$. Tak też uważał Celaleddin Arif, który chciał, aby dalej funkcjonowała osmańska Izba Deputowanych, uzupełniona jedynie o nowych członków. Kwestia przyszłego ustroju państwa zależała więc od tego, jaka opcja zwycięży w heterogenicznym WZN - radykalna, wiążąca się z odrzuceniem rozwiązań ustrojowych konstytucji osmańskiej z 1876 r. czy umiarkowana, zakładająca wypracowanie jakiegoś kompromisu ustrojowego między jej rozwiązaniami a zasadą suwerenności narodu proklamowaną w $1920 \mathrm{r}$.

\section{LINIE PODZIALÓW POLITYCZNYCH W I WIELKIM ZGROMADZENIU NARODOWYM}

Po uchwaleniu ustawy konstytucyjnej względna jedność WZN została przekreślona i wyłoniły się w nim różne grupy polityczne ${ }^{44}$. Pierwsza zorganizowana opozycja w okresie walki o niepodległość pojawiła się w reakcji na decyzję M. Kemala o konieczności wzmocnienia dyscypliny w Stowarzyszeniu Obrony Praw Anatolii i Rumelii w WZN. Zaapelował on do swoich zwolenników o utrzymanie jedności poglądów i działań poprzez poddanie się dyscyplinie na wzór partii rządzącej. Nazwa, jaką nadał w maju 1921 r. własnemu obozowi - Grupa Obrony Praw Anatolii i Rumelii (Mudafaa-î Hukuk Grubu), zwanej potocznie pierwszą grupą, była zaproszeniem skierowanym do oponentów do powołania drugiej grupy, powstałej w lipcu $1922 \mathrm{r}^{45}$

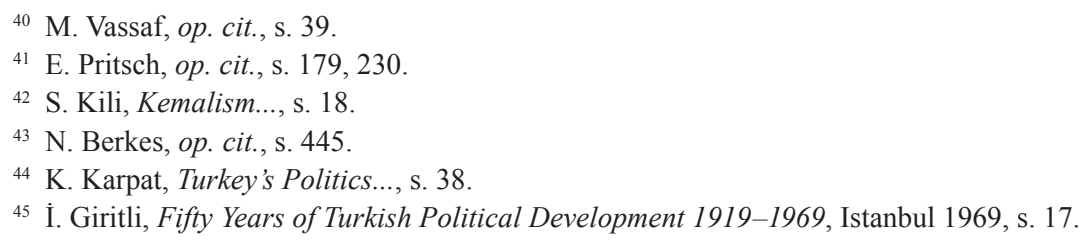


Źródłem podziałów była przede wszystkim kwestia ustrojowa, która musiała się pojawić ze względu na wskazane sprzeczności zawarte w ustawie konstytucyjnej z 1921 r. Problem sprowadzał się do pytania, czy na podstawie tego aktu należy tworzyć nowy ośrodek władzy, czy działać powoli, ostrożnie wobec dotychczasowego ośrodka władzy w Stambule. Członkowie drugiej grupy, choć potwierdzali zasady Paktu Narodowego, uważali ustawę konstytucyjną z $1921 \mathrm{r}$. za akt prawny o charakterze tymczasowym $^{46}$. Na początku 1922 r. Kâzım Karabekir Pasza wysłał do M. Kemala zaszyfrowaną wiadomość, w której pisał o konieczności uznania przepisów ustawy konstytucyjnej z 1921 r. za program partii, a nie za podstawę ustroju politycznego $0^{47}$. Wyraził obawę przed głoszonymi przez niektórych członków pierwszej grupy poglądami o konieczności zmiany ustroju politycznego i zastąpienia monarchii przez republikę oraz podkreślał, że nową koncepcję organizacji państwa popiera jedynie niewielka część narodu tureckie$\mathrm{go}^{48}$. Opozycja podkreślała, że nie jest przeciwna reformom ani nie zmierza do rozłamu w Stowarzyszeniu Obrony Praw, lecz opowiada się za demokratyczną, a nie autorytarną, metodą podejmowania decyzji politycznych ${ }^{49}$.

Innym źródłem konfliktów w WZN była obawa przed nadużyciem władzy przez M. Kemala, pełniącego na podstawie ustawy nr 144 funkcję naczelnego wodza i dysponującego pełnią władzy w Zgromadzeniu przez okres trzech miesięcy ${ }^{50}$. Obowiązywanie nadzwyczajnych uprawnień władczych Kemala były następnie trzykrotnie przedłużane na kolejne trzy miesiące oraz czwarty raz na czas nieograniczony „do osiągnięcia celu narodowego" ${ }^{51}$. Członkowie drugiej grupy dążyli do położenia kresu rządom jednostki oraz do powrotu do konstytucyjnej władzy WZN. Żądali również rządów prawa oraz zmian w prawie konstytucyjnym przez wprowadzenie zasady solidarnej odpowiedzialności rządu powoływanego przez przewodniczącego WZN i zaakceptowanego przez Zgromadzenie ${ }^{52}$. W tym zakresie rezolucja WZN z dnia 14 kwietnia $1923 \mathrm{r}$. spełniła oczekiwania opozycji, ponieważ na jej mocy stworzono urząd samodzielnego szefa rządu, który mógł być pośrednikiem między parlamentem a KDW oraz „autorytetem

46 S. Kili, Kemalism, s. 29.

${ }^{47}$ E.D. Smith, op. cit., s. 84; K. Karpat, Turkey's Politics..., s. 38.

48 İ. Giritli, Fifty Years..., s. 17.

49 E.D. Smith, op. cit., s. 81; K. Karpat, Turkey's Politics..., s. 38.

${ }^{50}$ T. Wituch, op. cit., s. 265; P. Kinross, Atatürk. The Rebirth of A Nation, London 1995, s. 271; S.J. Shaw, E.K. Shaw, op. cit., s. 360. Latem 1921 r., kiedy Grecy wkroczyli w głąb Anatolii, M. Kemal nakazał odstąpić im 100 mil terytorium tureckiego, co zostało negatywnie przyjęte przez parlament. WZN zażądało, aby na czele armii stanęła osoba odpowiedzialna za straty terytorialne, w czym zawierała się jednocześnie nadzieja przeciwników M. Kemala, że oczywista klęska wojenna położy kres także jego ambicjom politycznym.

${ }^{51}$ Były to ustawy: nr 160 z 31 października 1921 r.; nr 189 z 4 lutego 1922 r.; nr 229 z 6 maja 1922 r.; nr 245 z 20 lipca 1922 r. (G. Jäschke, E. Pritsch, Die Türkei seit dem Weltkriege, „Die Welt des Islams" 1927-1929, t. 10, s. 52 i n.; P. Kinross, op. cit., s. 305; E. Pritsch, Geschichtliche..., s. 182; K. Ziemke, Die neue Türkei, Berlin-Leipzig 1930, s. 380; E.D. Smith, op. cit., s. 52).

${ }^{52}$ H. Edib, op. cit., s. 203; W. Weiker, op. cit., s. 44; S.J. Shaw, E.K. Shaw, op. cit., s. 361; C. Dodd, Atatürk and Political Parties, [w:] Political Parties and Democracy in Turkey, red. M. Heper, J.M. Landau, London-New York 1991, s. 31. 
konsultacyjnym" dla delegatów wykonawczych. Wprowadzała również po raz pierwszy w historii Turcji odpowiedzialność solidarną członków KDW wobec WZN ${ }^{53}$.

Opozycja popierała także likwidację trybunałów niepodległości powołanych do sądzenia osób oskarżonych o popełnienie zbrodni przeciwko narodowi, zmiany w prawie wyborczym, ustanowienie zasady apolityczności przewodniczącego WZN i delegatów wykonawczych ${ }^{54}$. Żądano szacunku dla islamu oraz uznano, że religia nie sprzeciwia się nauce ani postępowi, krytykowano też innowacje niezgodne $\mathrm{z}$ duchem narodowym i ekstremalny konserwatyzm ${ }^{55}$.

Druga grupa mimo braku większości parlamentarnej była jednak w stanie głównie ze względu na wyjazdy stronników M. Kemala poza Ankarę oraz zmiany przynależności organizacyjnej niektórych posłów - przeforsować własne zamierzenia legislacyjne mające na celu ograniczenie pozycji ustrojowej przewodniczącego WZN $^{56} .8$ lipca 1922 r. Zgromadzenie Narodowe zmieniło ustawę z dnia 2 maja $1920 \mathrm{r}$. Przewodniczącemu WZN odebrano prawo przedstawiania parlamentowi kandydatów na delegatów wykonawczych, powracając do rozwiązania pierwotnego, upoważniającego parlament do ich wyboru w tajnym głosowaniu. Ustawą z 8 lipca 1922 r. Zgromadzenie oddzieliło ponadto przewodniczenie Komitetowi Delegatów Wykonawczych od funkcji przewodniczącego Zgromadzenia, odbierając M. Kemalowi tę pierwszą funkcję. Władza Kemala została w ten sposób uszczuplona, ponieważ w praktyce parlament aprobował kandydatury zgłaszane przez swego przewodniczącego ${ }^{57}$. Przewodniczącym KDW został wybrany w dniu 12 lipca 1922 r. Hüseyin Rauf (Orbay), członek drugiej grupy ${ }^{58}$.

Po ostatecznym zwycięstwie nad Grekami (sierpień-wrzesień 1922 r.) M. Kemal poczuł się na tyle silny, że mógł przystąpić do zniesienia sułtanatu. Podniósł w parlamencie, że skoro suwerenność w państwie należy do narodu, to sułtanat, którego podstawę stanowi zasada suwerenności jednostki, powinien zostać zniesiony. Jedynie kalifat jako organ władzy duchownej mógłby — według M. Kemala — pozostać w rękach następcy Vahideddina ${ }^{59}$. Opinię M. Kemala podzieliło WZN w uchwalonej 1 listopada 1922 r. ustawie nr 307 zawierającej dwa artykuły ${ }^{60}$. W pierwszym z nich deklarowano, że naród turecki uznaje formę rządów opartą na zasadzie suwerenności jednostki za wygasłą z mocą wsteczną od 16 marca 1920 r., czyli od dnia wprowadzenia formalnej

${ }^{53}$ Y. Altuğ, op. cit., s. 138; B. Lewis, op. cit., s. 440.

${ }^{54}$ W. Weiker, op. cit., s. 45; S.J. Shaw, E.K. Shaw, op. cit., s. 361; E. J. Zürcher, The Unionist Factor. The Role of the Committee of Union and Progress in the Turkish National Movement 1905-1926, Leiden 1984, s. 132.

55 E.J. Zürcher, op. cit., s. 132.

56 E. Özbudun, The Nature of the Kemalist..., s. 81.

57 A. Adamczyk, op. cit., s. 135. Tekst ustawy, [w:] E. Pritsch, Geschichtliche..., s. 183.

58 S.J. Shaw, E.K. Shaw, op. cit., s. 361.

59 N. Berkes, op. cit., s. 450; S. Kili, Kemalism..., s. 32.

${ }^{60}$ Jak podaje J.S. Łątka (Atatürk. Twórca nowoczesnej Turcji, Poznań 2016, s. 254), M. Kemal oznajmił na głosowaniu, że została ona przyjęta jednomyślnie, choć były głosy sprzeciwu wobec zniesienia sułtanatu. 
okupacji Stambułu przez wojska brytyjskie, a w drugim uznano kalifat za przynależny dynastii Osmanów, z zastrzeżeniem, że wybór kandydata, najlepszego ze względu na wykształcenie i charakter, należy do kompetencji Zgromadzenia ${ }^{61}$.

Zniesienie sułtanatu i pozostawienie kalifatu wywołało impas w WZN. Niezdecydowanie deputowanych w sprawie statusu kalifa, jak i przekonanie, że nowy parlament, cieszący się zaufaniem narodu i reprezentujący go, zostanie uznany przez aliantów za poważnego partnera w negocjacjach w Lozannie, sprawiły, że M. Kemal wpłynął na podjęcie przez Zgromadzenie 1 kwietnia 1923 r. uchwały o samorozwiązaniu WZN z dniem 16 kwietnia $1923 \mathrm{r}^{62}$ Czołowi przedstawiciele drugiej grupy: Refet Pasza (Bele), Kâzım Karabekir Pasza, Ali Fuad Pasza (Cebesoy), Hüseyin Rauf (Orbay), Adnan (Adıvar), nie chcąc w chwili negocjacji prowadzonych z rządami alianckimi w Lozannie rozbijać obozu narodowego, zdecydowali się na udział w wyborach do WZN z listy sporządzonej przez M. Kemala i pierwszą grupę. W ten sposób inni członkowie drugiej grupy nie zostali wpisani na listy wyborcze Stowarzyszenia Obrony Praw i nie weszli do nowego, liczącego 286 posłów Zgromadzenia Narodowego $^{63}$. Wybory do II WZN odbyły się — zdaniem konstytucjonalisty Bülenta Tanöra w warunkach eliminacji opozycji ${ }^{64}$.

\section{PODSUMOWANIE}

W latach 1919-1922 główne decyzje polityczne mające wpływ na kształt ustroju politycznego podjęło Stowarzyszenie Obrony Praw Anatolii i Rumelii. Wybory i zwołanie WZN w 1920 r., uchwalenie ustawy konstytucyjnej w 1921 r., wojna z Grecją, przygotowanie programu populizmu - głównego dokumentu wskazującego na założenia ideologiczne ruchu oporu, zniesienie sułtanatu — odbyło się pod auspicjami tego Stowarzyszenia. M. Kemal pełnił wprawdzie w WZN eksponowaną funkcję przewodniczącego parlamentu i naturalnego szefa KDW, ale wszystkie jego działania podlegały kontroli Zgromadzenia wyłonionego przez Stowarzyszenie. Należy też zauważyć, że mimo heterogenicznego składu i mocnego przywiązania do islamu I WZN odeszło od podstawowych założeń, na których opierało się państwo osmańskie. Parlament przyjął wszak, że suwerenność bezwarunkowo przynależy narodowi, a WZN było wyrazem woli narodu i źródłem, z którego wypływały kompetencje innych organów. W tym sensie za zasadny można uznać pogląd, zgodnie z którym był to organ o charakterze rewolucyjnym.

${ }^{61}$ Vide E. Pritsch, Geschichtliche..., s. 185; M. Vassaf, op. cit., s. 90; İ. Giritli, Fifty Years..., s. 15; K.H. Karpat, Turkey's Politics..., s. 40; W. Hale, Turkish Politics and the Military, New York 1994, s. 62; Y. Altuğ, op. cit., s. 137.

${ }^{62}$ İ. Giritli, Fifty Years..., s. 19; K. Karpat, Turkey's Politics..., s. 42; G. Jäschke, E. Pritsch, op. cit., s. 73.

${ }^{63}$ L.L. Roos, N.P. Roos, Managers of Modernization. Organizations and Elites in Turkey (1950-1969), Cambridge 1971, s. 24; W. Weiker, op. cit., s. 188; I. Giritli, Fifty Years..., s. 19; W. Hale, Turkish Politics..., s. 68; G. Harris, The Role of the Military in Turkish Politics, „The Middle East Journal” 1965, t. 19, nr 1, s. 57; İ. Turan, Continuity and Change in Turkish Bureaucracy: The Kemalist Period and After, [w:] Atatürk and the Modernization of Turkey, red. J.M. Landau, Leiden 1984, s. 111; E.J. Zürcher, The Unionist Factor, s. 132.

${ }^{64}$ B. Tanör, op. cit., s. 139 i n. 
Reforma ustroju politycznego nie została jednak ukończona. Przeforsowana następnie przez M. Kemala w II WZN proklamacja republiki zintensyfikowała konflikt w partii rządzącej, od dnia 9 sierpnia 1923 r. występującej pod nazwą Partii Ludowej. W drugiej połowie 1923 r. nie było już wątpliwości, że M. Kemal zamierza przeprowadzić szeroki program modernizacji Turcji. Istniały przesłanki wskazujące na to, że zamierzał on znieść kalifat i zreformować prawo cywilne. Starcie dwóch opcji modernizacyjnych, reprezentowanych przez Republikańską Partię Ludową M. Kemala i Postępową Partię Republikańską z generałami o wielkim autorytecie: Alim Fuadem (Cebesoy), Kâzımem Karabekirem, Refetem (Bele), Raufem (Orbay) i Cafferem Tayarem (Eğilmez) było w II WZN nieuniknione.

BIBLIOGRAFIA

Abadan Y., Die Entstehung der Türkei und ihre verfassungsrechtliche Entwicklung bis 1960, „Jahrbuch des öffentlichen Rechtsgeschichte” 1960, nr 9.

Adamczyk A., Ustrój polityczny Turcji w latach 1918-1960, DiG, Warszawa 2013.

Altuğ Y., The Development of Constitutional Thought in Turkey, [w:] Modern Turkey: Continuity and Change, red. A. Evin, Leske Verlag and Budrich, Opladen 1984, https://doi. org/10.1007/978-3-663-01177-4_7.

Apaydın O., Historyczny rozwój tureckiego prawa, „Palestra” 1978, nr 8.

Başgil A.F., A Summary of Constitutional Developments in Turkey and on the Historical and Political Sources of the Present Constitution, „Annales de la Faculté de Droit d'Istanbul” 1960, nr 15.

Berkes N., The Development of Turkish Secularism, McGill University Press, Montreal 1964.

Dodd C., Atatürk and Political Parties, [w:] Political Parties and Democracy in Turkey, red. M. Heper, J.M. Landau, I.B. Tauris and Co. Ltd. Publishers, London-New York 1991.

Edib H., Turkey Faces West, Yale University Press, New Haven 1930.

Frey F., The Turkish Political Elite, M.I.T. Press, Cambridge 1965.

Giritli İ., Fifty Years of Turkish Political Development 1919-1969, Fakülteler Matbaas1, Istanbul 1969.

Giritli İ., Kemalism as an Ideology of Modernization, [w:] Atatürk and the Modernization of Turkey, red. J.M. Landau, Westview Press / E.J. Brill, Leiden 1984.

Hale W., Turkish Politics and the Military, Routledge, New York 1994.

Harris G., The Role of the Military in Turkish Politics, „The Middle East Journal” 1965, t. 19, nr 1.

Hirsch E., Die Verfassung der türkischen Republik, Metzner Verlag, Frankfurt am Main-Berlin 1966.

Jäschke G., Auf dem Wege zur Türkischen Republik. Ein Beitrag zur Verfassungsgeschichte der Türkei, „Die Welt des Islams” 1958, t. V, nr 3-4.

Jäschke G., Der Islam in der neuen Türkei. Eine Rechtsgeschichtliche Untersuchung, „Die Welt des Islams" 1951, t. I, nr 1-2.

Jäschke G., Pritsch E., Die Türkei seit dem Weltkriege, „Die Welt des Islams” 1927-1929, t. 10.

Karal E.Z., The principles of Kemalism, [w:] Atatürk. Founder of A Modern State, red. A. Kazancigil, E. Özbudun, Hurst \& Co., London 1997.

Karpat K., Turkey's Politics. The Transition to A Multi-Party System, Princeton University Press, Princeton 1959.

Kemal M. (Atatürk), A Speech Delivered by Mustafa Kemal Atatürk 1927, Başbakanlık Basımevi, Ankara 1981.

Kentel F., Nowoczesność i islam w Turcji, „Krytyka” 1994, nr 44/45. 
Kili S., Kemalism, Robert College Publications, Istanbul 1969.

Kili S., Turkish Constitutional Developments and Assembly Debates on the Constitution of 1924 and 1961, Robert College Research Center, Istanbul 1971.

Kinross P., Atatürk. The Rebirth of A Nation, Phoenix, London 1995.

Kohn H., Geschichte der nationalen Bewegung im Orient, Kurt Vowinckel Verlag, Berlin-Grunewald 1928.

Lewis B., Narodziny nowoczesnej Turcji, Państwowe Wydawnictwo Naukowe, Warszawa 1972.

Łątka J.S., Atatürk. Twórca nowoczesnej Turcji, Wydawnictwo Poznańskie, Poznań 2016.

Macfie A.L., Atatürk, Longman, London-New York 1994.

Maddex R.L., Constitutions of the World, CQ Press, Washington 2001.

Orga I., Phoenix Ascendant: The Rise of Modern Turkey, Robert Hale, London 1958.

Özbudun E., The Nature of the Kemalist Political Regime, [w:] Atatürk. Founder of A Modern State, red. A. Kazancigıl, E. Özbudun, Hurst \& Co., London 1997.

Özbudun E., Turkey, [w:] Competitive Elections in Developing Countries, red. M. Weiner, E. Özbudun, Duke University Press, Durham 1987.

Özbulak Z.K., Das türkische Verfassungssystem, Triltsch \& Huther, Berlin 1936.

Pannenkowa I., Przewrót w Turcji, „Rzeczpospolita”, 6 III 1924, nr 65.

Pritsch E., Geschichtliche und systematische Übersicht nebst Anmerkungen zur Verfassung, „Mitteilungen des Seminars für Orientalische Sprachen zu Berlin” XXVI-XXVII (1924), t. II.

Roos L.L., Roos N.P., Managers of Modernization. Organizations and Elites in Turkey (1950-1969), Harvard University Press, Cambridge 1971, https://doi.org/10.4159/harvard.97806 74423190.fm.

Rumpf Ch., Das Rechtsstaatsprinzip in der türkischen Rechtsordnung. Ein Beitrag zum türkischen Verfassungsrecht und zur europäischen Rezeptionsgeschichte, Bouvier, Bonn-Berlin 1992.

Rustow D.A., Atatürk as an Institution-builder, [w:] Atatürk. Founder of A Modern State, red. A. Kazancigıl, E. Özbudun, Hurst \& Co., London 1997.

Rustow D.A., The Modernization of Turkey in Historical and Comparative Perspective, [w:] Social Change and Politics in Turkey. A Structural-Historical Analysis, red. K. Karpat, E.J. Brill, Leiden 1973.

Shaw S.J., Shaw E.K., History of the Ottoman Empire and Modern Turkey, vol. II: Reform, Revolution and Republic: The Rise of Modern Turkey 1808-1975, Cambridge University Press, Cambridge 1977, https://doi.org/10.1017/CBO9780511614972.

Smith E.D., Turkey: Origins of the Kemalist Movement and the Government of the Grand National Assembly (1919-1923), Judd \& Detweiler, Washington 1959.

Starzyński S., Powojenny ustrój państw europejskich, [b.o.w.], Kraków 1926.

Tanör B., The Place of Parliament in Turkey, [w:] Turkish State, Turkish Society, red. A. Finkel, N. Sirman, Routledge, London-New York 1990.

Tunaya T.Z., Ideologic Character of the 1924 Constitution, „Annales de la Faculté de Droit d'Istanbul" 1960, nr 15, t. X.

Tunaya T.Z., The Establishment of the Government of the Turkish Grand National Assembly and Its Political Character, „Annales de la Faculté de Droit d'Istanbul” 1963, nr 19, t. XIII.

Turan İ., Continuity and Change in Turkish Bureaucracy: The Kemalist Period and After, [w:] Atatürk and the Modernization of Turkey, red. J.M. Landau, E.J. Brill, Leiden 1984.

Türsan H., Democratisation in Turkey: the role of political parties, Peter Lang S.A., Brussels 2004.

Weiker W., Political Tutelage and Democracy in Turkey. The Free Party and Its Aftermath, E.J. Brill, Leiden 1973. 
Webster D., The Turkey of Atatürk. Social Process in the Turkish Reformation, The Collegiate Press, Philadelphia 1939.

Wituch T., Tureckie przemiany. Dzieje Turcji 1878-1923, Państwowe Wydawnictwo Naukowe, Warszawa 1980.

Vassaf M., Die Grundideen des türkischen Staatswesen und seine stufenweise Entwicklung, „Abhandlung des Instituts für Politik, ausländisches öffentliches Recht und Völkerrecht an der Universität Leipzig", Heft 39, R. Noske, Leipzig 1934.

Ziemke K., Die neue Türkei, Deutsche Verlags-Anstalt, Berlin-Leipzig 1930.

Zürcher E.J., Political Opposition in the Early Turkish Republic. The Progressive Republican Party 1924-1925, E.J. Brill, Leiden-New York-Kobenhavn-Köln 1991.

Zürcher E.J., The Unionist Factor. The Role of the Committee of Union and Progress in the Turkish National Movement 1905-1926, E.J. Brill, Leiden 1984.

Zwierzchowski E., Organizacja i funkcjonowanie Sadu Konstytucyjnego Republiki Turcji, [w:] Sady konstytucyjne w Europie. Akty normatywne wedlug stanu prawnego na dzień 1 lipca 1999 r., t. 3: Hiszpania, Portugalia, Turcja, red. J. Trzciński, Trybunał Konstytucyjny, Warszawa 1999. 